\title{
Giant bilateral primary scrotal lipoma along with lipomas in multiple sites of the body: a case report and literature review
}

\author{
Weitao Zheng ${ }^{1 \#}$, Ming Shi ${ }^{1 \#}$, Tao Li ${ }^{2 \#}$, Hang $\mathrm{Xu}^{1}$, Zeyu Chen ${ }^{1}$, Xingyuan Wang ${ }^{1}$, Shengjiang Bai ${ }^{1}$, \\ Weizhen Le ${ }^{1}$, Lu Yang ${ }^{1}$, Qiang Wei ${ }^{1}$ \\ ${ }^{1}$ Department of Urology, Institute of Urology, West China Hospital, Sichuan University, Chengdu, China; ${ }^{2}$ Department of Gynecology and \\ Obstetrics, Development and Related Disease of Women and Children Key Laboratory of Sichuan Province, Key Laboratory of Birth Defects and \\ Related Diseases of Women and Children, Ministry of Education, West China Second Hospital, Sichuan University, Chengdu, China \\ \#These authors contributed equally to this work. \\ Correspondence to: Dr. Lu Yang; Dr. Qiang Wei. Department of Urology, West China Hospital, Sichuan University, No. 37, Guoxue Road, Chengdu \\ 610041, China. Email:wycleflue@163.com; weiqiang933@126.com.
}

\begin{abstract}
Mesenchymal neoplasms of the scrotum are extremely rare in the clinical practices, in which lipoma is the most common benign neoplasm of them. Primary scrotal lipoma refers to the lipoma originated from scrotal wall. We reported a rare case of a 47 -year-old man who suffered from bilateral giant primary scrotal lipoma along with lipomas in multiple sites of the body. Scrotal ultrasound indicated that huge hypoechogenic masses were observed in the bilateral scrotums. Contrast-enhanced computed tomography (CT) indicated increased fat density in the scrotal areas. Surgical resection was performed on both scrotal neoplasms. Diagnosis of lipoma was confirmed by the pathological examination through the morphological observation as well as the absence of murine double minute2 (MDM2) gene amplification in the fluorescence in situ hybridization (FISH) test. After five months of follow-up, the wound of the patient recovered well and no sign of local recurrence was observed. Based on the literature review, very few cases of primary scrotal lipoma were reported in the scientific literature up to date, and this is the first report of bilateral primary scrotal lipoma along with multiple lipomas of the body. We presented this case as a rare phenomenon. Although primary scrotal lipoma is rare, clinicians should take it into account when encountering similar scrotal lesions and know the methods for diagnosis and how to make differential diagnosis with other diseases, which is associated with the patient's treatment strategy and prognosis.
\end{abstract}

Keywords: Primary scrotal lipoma; treatment; diagnosis; case report

Submitted Jul 07, 2020. Accepted for publication Nov 18, 2020.

doi: $10.21037 /$ tau-20-1073

View this article at: http://dx.doi.org/10.21037/tau-20-1073

\section{Introduction}

Lipoma is the most common benign neoplasm in the scrotal mesenchymal neoplasms which is extremely rare in the clinical practice. Once intrascrotal lesion is detected, lipoma should be taken into account. Scrotal lipoma always originates from the spermatic cord, however, in some rare cases, it can originate outside the spermatic cord such as the scrotal wall $(1,2)$. This article reported a case of a giant bilateral primary scrotal lipoma diagnosed by pathological examination via surgical resection in a 47 -year-old man referred to our department along with lipomas in multiple sites of the body. Based on our literature review, very few cases of primary scrotal lipomas were reported in the scientific literature especially along with multiple lipomas in multiple sites of the body, so we regard this case as a rare one. We present the following article in accordance with the CARE reporting checklist (3) (available at http://dx.doi. org/10.21037/tau-20-1073). 

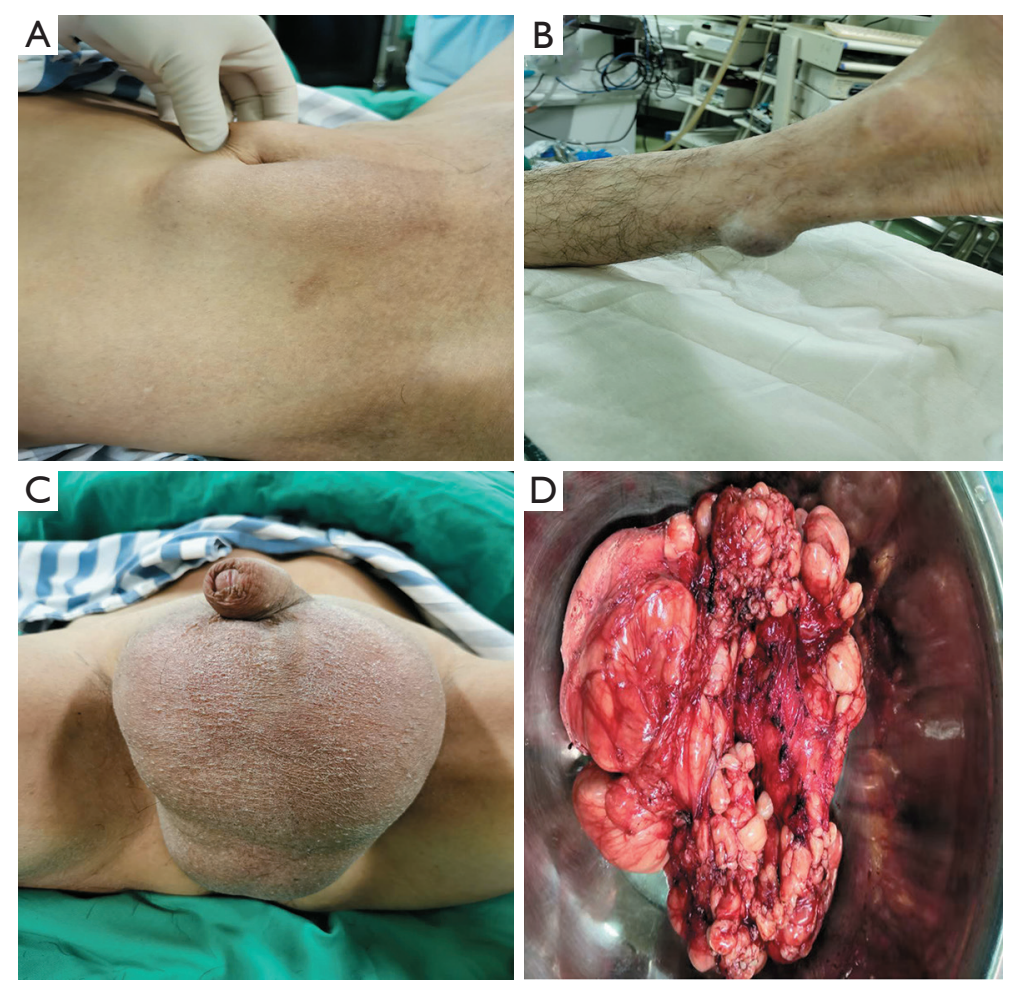

Figure 1 Scrotal lipoma with part of lipomas in multiple sites of the body and surgical specimen. (A) Lipoma in peripheral umbilicus. (B) Lipoma in left Achilles tendon. (C) Giant bilateral scrotal lipoma. (D) Surgical specimen after surgical excision.

\section{Case presentation}

A 47 years old man was admitted to our hospital due to the progressively enlarging lumps which was found accidentally in the bilateral scrotums since 8 months ago. These lumps were painless and movable, whose size increased gradually. In particular, the patient found similar lumps occurred in cervical occipital, pectoral back, peripheral umbilicus and left Achilles tendon successively. No significant positive history was provided to help speculate the pathogenesis of the lumps. A comprehensive and systematic physical examination was conducted when the patient was admitted, which showed the results that the lumps in the scrotums were approximately $10 \mathrm{~cm} \times 5 \mathrm{~cm}$ in both sides, the cervical occipital was $12 \mathrm{~cm} \times 9 \mathrm{~cm}$, the pectoral back was multiple and variable-sized, the peripheral umbilicus was $10 \mathrm{~cm} \times 8 \mathrm{~cm}$ and the left Achilles tendon was $2.5 \mathrm{~cm} \times 2 \mathrm{~cm}$ (Figure 1). The lumps appeared to be painless, non- tender, movable and soft with clear margins. Both testes were not invaded.

A series of examinations were arranged for the patient in order to clarify the diagnosis. The scrotal ultrasound revealed the existence of huge hypoechogenic masses in the bilateral scrotums, the mass size of the right side was about $9.9 \mathrm{~cm} \times 4.5 \mathrm{~cm}$, and the left side was about $10.8 \mathrm{~cm} \times 5.6 \mathrm{~cm}$. Both sides could be deformed by compression with little punctate blood flow signal inside. The testis whose shape and size were not aberrant was pushed into the bilateral inguinal area. Fat-derived tumors were suspected. Contrast-enhanced computed tomography (CT) results indicated the increased fat density in submandibular space, cervical root, item subcutaneous and both scrotal areas. Fat accumulation or lipoma was taken into account (Figure 2).

After the comprehensive preoperative preparation, the patient underwent surgery resection under general anesthesia. A $12 \mathrm{~cm}$ scrotal vertical incision was given, both sides of the scrotum were enlarged, and there were multiple lobulated large lipomas with complete capsule in the scrotums. The masses were soft, yellow, and irregular in shape. These masses were covered with capsules and slightly adhered to the surrounding tissues (Figure 1D). The lipomas were separated from the testes completely. The incision was sewed up after complete hemostasis. No adverse event was observed during the perioperative period. The pathological 

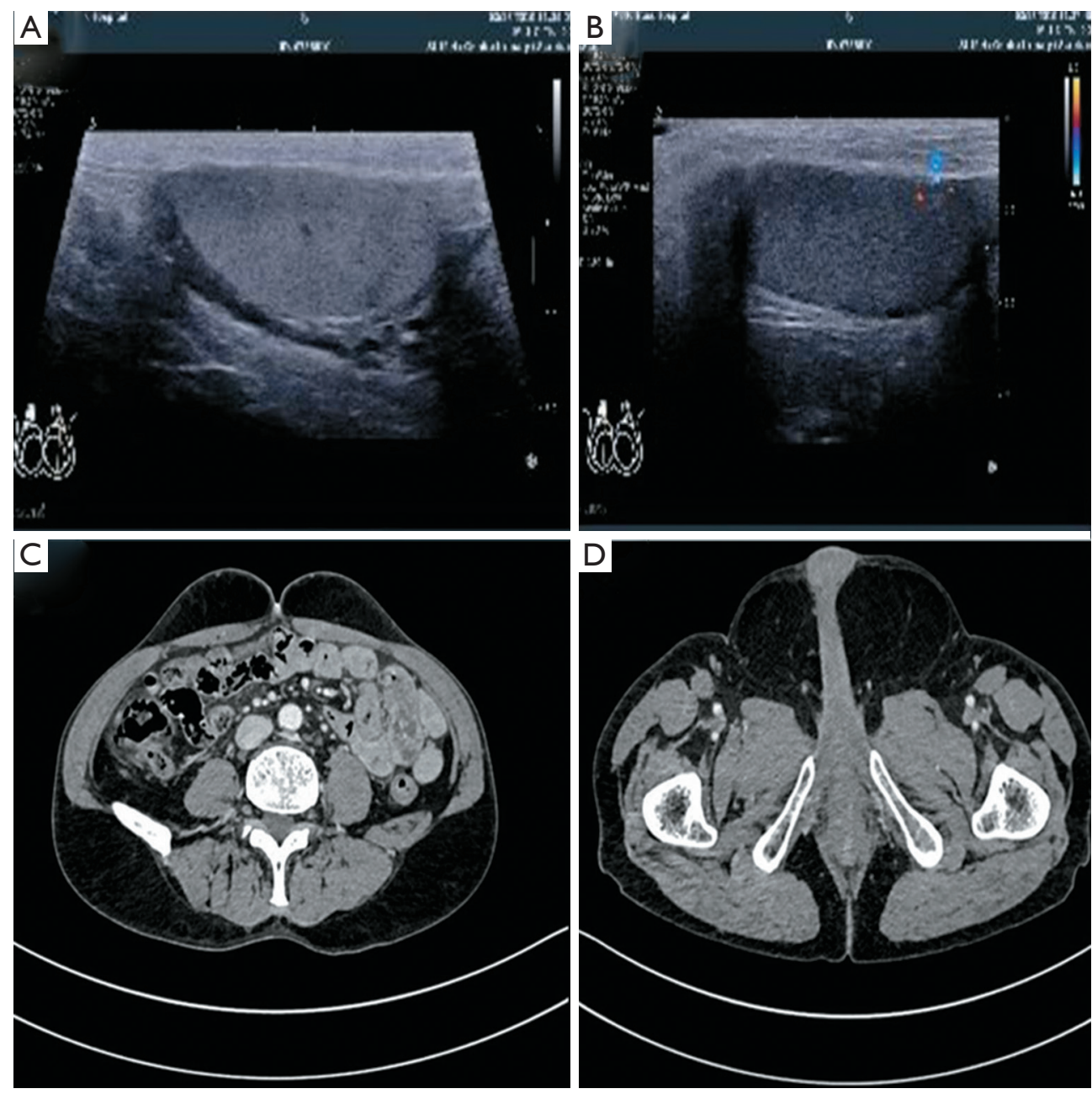

Figure 2 Ultrasound and CT images of the lipomas. (A) Ultrasound image of left testis and epididymis. (B) Ultrasound image of right testis and epididymis. (C) CT image of umbilical lipoma. (D) CT image of scrotal lipoma.

examination indicated a fat-derived tumor. The absence of MDM2 gene was confirmed by FISH test, thus identified the diagnosis of lipoma combined with morphological observation. After five months of follow-up, the wound of the patient recovered well and no recurrence was observed (Figure 3). All procedures performed in studies involving human participants were in accordance with the ethical standards of the Ethics committee on biomedical research, West China Hospital of Sichuan University and with the Helsinki Declaration (as revised in 2013). Written informed consent was obtained from the patient.

\section{Discussion}

The majority of the tumors arised from the extratesticular mesenchymal soft tissues are benign tumors, including lipoma, leiomyoma and fibrous pseudotumor. Lipoma is the most common benign neoplasm of the scrotum (4). Fujimura et al. proposed a classification of scrotal lipomas in consideration of the site of origin: (I) Scrotal lipoma: originated in the spermatic cord with spread to the scrotum. (II) Spermatic cord and tunica vaginalis tumor: originated and developed within the cord. (III) Primary scrotal lipoma: originated within the scrotum (5). According to the classification, scrotal lipoma of this case should be classified as a primary scrotal lipoma.

We conducted a literature search extensively on authenticated databases including PubMed/Medline, Embase, and Web of Science. MeSH terms 'Scrotum' and 'Lipoma' were used as searching strategy, obvious 


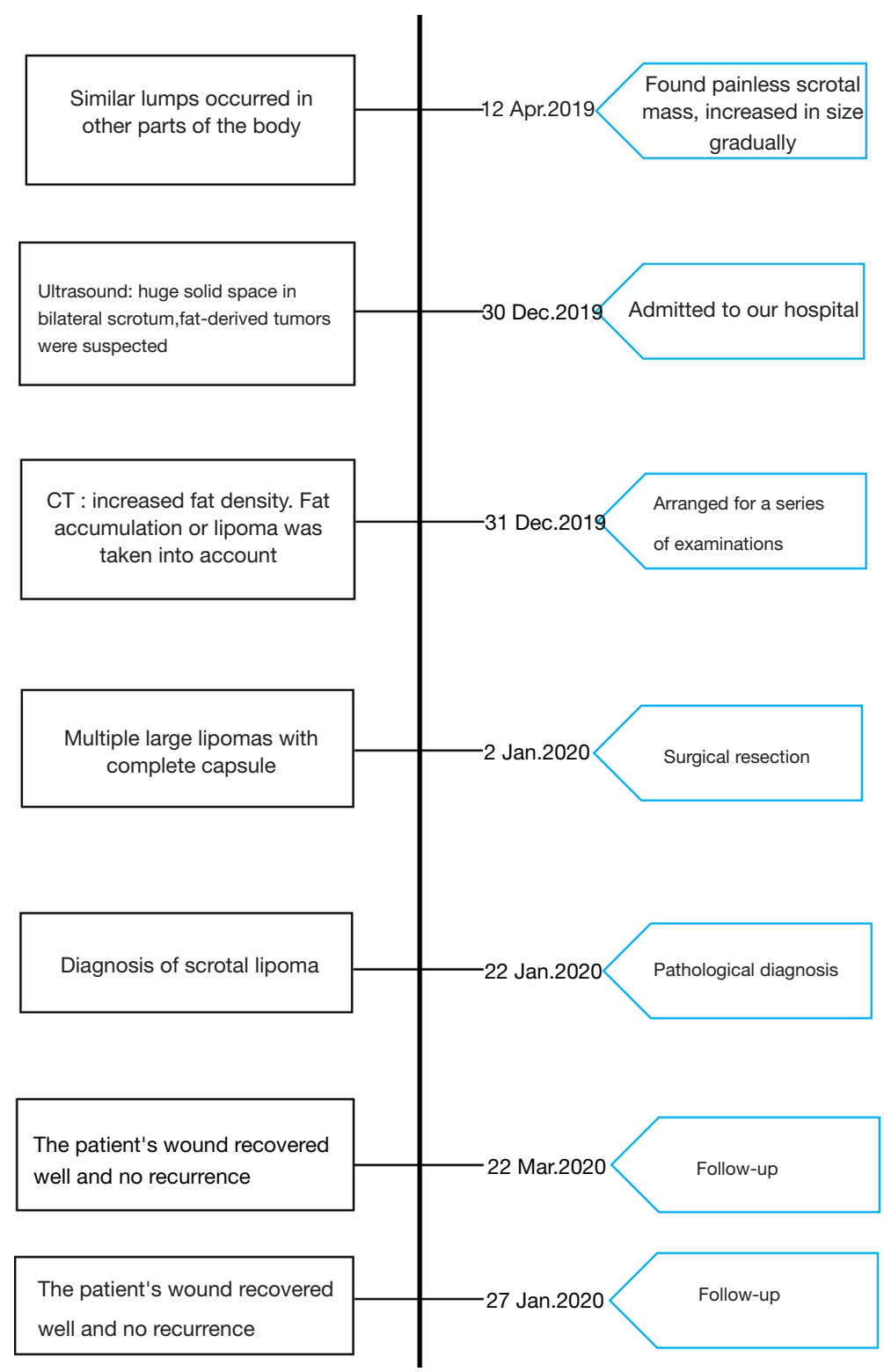

Figure 3 Timeline of the treatment procedure

duplicates were removed, and cases with inaccessible full texts were excluded. Initially, we included all of the cases reported in English with full texts (Table 1). The age of scrotal lipoma patients ranged from 1 month to 76 years, the mean age was 45.7 years and the median age was 49 years. It was more commonly occurred on the left scrotum $(7 / 16,43.75 \%)$ rather than the others, while bilateral scrotums involved were quite rare (1/16, 6.25\%). According to our literature review, very few cases of primary scrotal lipomas were reported in the scientific literature.
Since the first report by Livermore et al. in 1948 (6), only 16 cases of scrotal lipoma have been reported until now, and this is the first report of bilateral primary scrotal lipoma along with multiple lipomas of the body up to date. However, this case needs to be distinguished from Madelung's disease which is a rare benign lesion caused by abnormal metabolism of adipose tissue which has characteristics of excessive, progressive, and symmetrical deposits of adipose tissue in the subcutaneous layer (17). Madelung disease usually occurs in the head and neck, upper trunk, and 
Table 1 Patients' information of the case reports of literature review

\begin{tabular}{|c|c|c|c|c|c|c|c|c|}
\hline $\begin{array}{l}\text { No. } \\
\text { (ref.). }\end{array}$ & Authors (year) & $\begin{array}{l}\text { Age } \\
\text { (years) }\end{array}$ & Place & Clinical manifestation & Ways to diagnose & Therapy & $\begin{array}{l}\text { Follow-up } \\
\text { (months) }\end{array}$ & $\begin{array}{l}\text { Outcome/ } \\
\text { prognosis }\end{array}$ \\
\hline $1,(6)$ & $\begin{array}{l}\text { Livermore } \\
\text { et al. (1948) }\end{array}$ & 75 & Left side & $\begin{array}{l}\text { Painless mass, sense } \\
\text { of weight and pressure, } \\
\text { increased in size }\end{array}$ & Pathology & $\begin{array}{l}\text { Surgical } \\
\text { resection }\end{array}$ & N/A & N/A \\
\hline $2,(7)$ & $\begin{array}{l}\text { Cullough } \\
\text { et al. (1953) }\end{array}$ & 49 & Left side & $\begin{array}{l}\text { Painless mass, } \\
\text { uncomfortable, sense of } \\
\text { pressure }\end{array}$ & $\begin{array}{l}\text { Physical examination, } \\
\text { Pathology }\end{array}$ & $\begin{array}{l}\text { Surgical } \\
\text { resection }\end{array}$ & $\mathrm{N} / \mathrm{A}$ & N/A \\
\hline $3,(8)$ & $\begin{array}{l}\text { Florante } \\
\text { et al. (1976) }\end{array}$ & 20 & Right side & Painless mass & $\begin{array}{l}\text { Physical examination, } \\
\text { Pathology }\end{array}$ & $\begin{array}{l}\text { Surgical } \\
\text { resection }\end{array}$ & $\mathrm{N} / \mathrm{A}$ & Uneventful \\
\hline 4, (8) & $\begin{array}{l}\text { Florante } \\
\text { et al. (1976) }\end{array}$ & 76 & Right side & Painless mass & $\begin{array}{l}\text { Physical examination, } \\
\text { Pathology }\end{array}$ & $\begin{array}{l}\text { Surgical } \\
\text { resection }\end{array}$ & $\mathrm{N} / \mathrm{A}$ & N/A \\
\hline $7,(9)$ & $\begin{array}{l}\text { Rosenberg } \\
\text { et al. (1989) }\end{array}$ & N/A & N/A & Scrotal swelling & Ultrasonography, CT & $\begin{array}{l}\text { Surgical } \\
\text { resection }\end{array}$ & $\mathrm{N} / \mathrm{A}$ & $\mathrm{N} / \mathrm{A}$ \\
\hline $8,(10)$ & $\begin{array}{l}\text { Szmigielski } \\
\text { et al. (2000) }\end{array}$ & 67 & Both sides & Scrotal swelling & $\begin{array}{l}\text { Physical examination, } \\
\text { Ultrasonography, CT, } \\
\text { Pathology }\end{array}$ & $\begin{array}{l}\text { Surgical } \\
\text { resection }\end{array}$ & N/A & N/A \\
\hline $9(11)$ & $\begin{array}{l}\text { Edelstein } \\
\text { et al. (2009) }\end{array}$ & 48 & N/A & Scrotal swelling & Pathology & $\begin{array}{l}\text { Surgical } \\
\text { resection }\end{array}$ & N/A & N/A \\
\hline $10,(12)$ & $\begin{array}{l}\text { Kim et al. } \\
(2009)\end{array}$ & 1 month & Midline & $\begin{array}{l}\text { Pendulous scrotal mass, } \\
\text { increased in size }\end{array}$ & Ultrasound, Pathology & $\begin{array}{l}\text { Surgical } \\
\text { resection }\end{array}$ & $\mathrm{N} / \mathrm{A}$ & $\mathrm{N} / \mathrm{A}$ \\
\hline $13,(1)$ & $\begin{array}{l}\text { Fabiani } \\
\text { et al. (2016) }\end{array}$ & 22 & Left side & Painful mass & $\begin{array}{l}\text { Physical examination, } \\
\text { Ultrasonography, } \\
\text { Pathology }\end{array}$ & $\begin{array}{l}\text { Surgical } \\
\text { resection }\end{array}$ & $\mathrm{N} / \mathrm{A}$ & N/A \\
\hline $14,(15)$ & $\begin{array}{l}\text { Creta et al. } \\
(2017)\end{array}$ & 54 & Midline & $\begin{array}{l}\text { Scrotal swelling, } \\
\text { discomfort }\end{array}$ & $\begin{array}{l}\text { Physical examination, } \\
\text { Ultrasonography, MRI, } \\
\text { Pathology }\end{array}$ & $\begin{array}{l}\text { Surgical } \\
\text { resection }\end{array}$ & N/A & N/A \\
\hline $15,(2)$ & $\begin{array}{l}\text { Srivastava } \\
\text { et al. (2017) }\end{array}$ & 29 & Left side & $\begin{array}{l}\text { Painless mass, } \\
\text { increased in size. }\end{array}$ & $\begin{array}{l}\text { Physical examination, } \\
\text { Ultrasonography, MRI, } \\
\text { Pathology }\end{array}$ & $\begin{array}{l}\text { Surgical } \\
\text { resection }\end{array}$ & $\mathrm{N} / \mathrm{A}$ & Uneventful \\
\hline $16,(16)$ & $\begin{array}{l}\text { Yamamichi } \\
\text { et al. (2018) }\end{array}$ & 58 & Left side & $\begin{array}{l}\text { Scrotal swelling, } \\
\text { discomfort }\end{array}$ & $\begin{array}{l}\text { CT, MRI, PET-CT, } \\
\text { Pathology }\end{array}$ & $\begin{array}{l}\text { Surgical } \\
\text { resection }\end{array}$ & Six & $\begin{array}{l}\text { No } \\
\text { recurrence }\end{array}$ \\
\hline
\end{tabular}

N/A, not available; CT, computed tomography; MRI, magnetic resonance imaging; PET-CT, positron emission tomography-computed tomography. 
proximal portions of the upper extremities, specific and rare sites such as scrotal involvement associated with bilateral asymmetrical gynaecomastia were also reported previously, which seemed quite similar to the case in this study. Lipoma also has similar imaging manifestations to the Madelung disease, while the key to distinguish lipoma from fatty nonencapsulated tissue of Madelung disease is the complete capsules of the lipoma (18). In our case, the surgical specimen of the patient had complete capsules, proving that it was lipoma.

In addition to the comprehensive and systematic physical examination, ultrasonography and imaging examinations play critical roles in the evaluation of scrotal masses. Ultrasonography is recommended as one of the firstline examinations in the identification of lipomas due to its high feasibility as well as the ability to distinguish cystic or solid lesions under both intra- or extra-testicular conditions. Lipoma is usually characterized as a welldefined, ovalar, sometimes capsulated and "striped" mass in ultrasound images, which lacks internal blood flow. However, ultrasound findings are often nonspecific and may be variable $(4,19)$. CT can detect subtle density differences and make anatomic assessment accurately. The unique tissue density of lipomatous masses is an obvious character that can be used to distinguish them from other soft tissue tumors. Lipomas, avascular at angiography, demonstrate a homogeneous, sharply marginated low density mass on CT scan, whereas liposarcoma with heterogeneous mixture of fat and water density presents heterogeneity, ill-defined margins, and contrast enhancement. However, it is still difficult to make a differential diagnosis with liposarcoma by CT in some cases. For example, the angiolipoma has similar features to the liposarcoma, which made it difficult to distinguish angiolipoma from liposarcoma although angiolipoma appears no definite invasion on the CT scan (20). Lipoma is similar to subcutaneous fat but may contain little thin septa and demonstrate a characterized appearance at magnetic resonance imaging (MRI) (21). It can be differentiated from liposarcoma by observing the absence of enhancement after administration of gadolinium contrast material. Imaging findings can often help urologists for both patient counseling and surgical planning $(2,4)$. Although the MRI imaging is sensitive, in some cases, however, there may be few non adipose components in a large lipoma such as blood vessels, fibrous tissues, and muscle fibers similar to a well differentiated liposarcoma, which made the differential diagnosis complicated $(14,22)$.

Symptoms vary with size and pressure caused by the lipoma. Our literature review results revealed that the most common symptoms were painless mass of the scrotum $(7 / 16,43.75 \%)$ and scrotal swelling or discomfort $(7 / 16$, $43.75 \%)$, followed by sense of weight and pressure $(2 / 16$, $12.50 \%)$ and painful mass $(1 / 16,6.25 \%)$. The patient in our case presented with painless mass of bilateral scrotums. All of the patients underwent surgical resection, the postoperative course was uneventful and no recurrence was observed after six months follow-up in two cases. Surgical resection remains predominant therapeutic regimen in the first-line treatment of a primary scrotal lipoma, simple enucleation through scrotal or combined scrotal and inguinal incision will suffice (2). Histopathology is always essential for diagnosis, sometimes genetic testing is needed for differential diagnosis in some cases. Amplification of MDM2 and cyclin-dependent kinase 4 (CDK4) genes are the most prominent genetic aberrations of ALTs and dedifferentiated liposarcoma (DDLPS). MDM2 gene amplification is a more reproducible and reliable method to diagnose DDLPS, the sensitivity and specificity of which was $100 \%$ and $83.3 \%$ respectively (23). In this case, the pathological examination indicated a fat-derived tumor and FISH test did not show amplification of MDM2 gene, the diagnosis of lipoma was confirmed combined with morphology.

In this study, a rare case of bilateral primary scrotal lipoma along with lipomas in multiple sites of the body is reported. Literature review was also conducted to summarize the features of scrotal lipoma, which could provide clinicians with ideas and methods for diagnosis when encountering such scrotal lesions. Meanwhile, we had proposed the differential diagnosis between scrotal lipoma and Madelung's disease, which was very similar to our case and needed to be paid attention to in clinical practices. Our limitations were that: (I) MRI was not performed in this patient, since MRI needed a relatively long time to make an appointment, while the patient required surgery resection as soon as possible. (II) Lipomas in other parts of the body confirmed by CT were symptomless and had no impact on the patient, the patient had no intention to remove them, so the pathological examination of lipomas in other parts were not available.

\section{Conclusions}

Primary scrotal lipomas are rare, benign paratesticular tumors, and pose significant diagnostic dilemma. Ultrasonography is one of the first-line examinations, 
and imaging examinations also play critical roles in the evaluation of scrotal masses. Histopathology and genetic testing are always essential for a precise diagnosis. Surgical resection remains predominant treatment in the first-line management of scrotal lipomas which can solve oppression symptoms and provide histopathologic diagnosis.

\section{Acknowledgments}

Funding: This work was supported by the National Key Research and Development Program of China (Grant No. SQ2017YFSF090096), National Natural Science Foundation of China (Grant Nos. 81974098, 81770756, 81974099 and 81702536), programs from Science and Technology Department of Sichuan Province (Grant Nos. 2018JY0089, 2017HH0063 and 2018HH0153), Young Investigator Award of Sichuan University 2017 (Grant No. 2017SCU04A17), Post-Doctor Research Project, West China Hospital, Sichuan University (2018HXBH042) and National Clinical Research Center for Geriatrics, West China Hospital, Sichuan University (Z2018C01) and a grant from 1.3.5 project for disciplines of excellence, West China Hospital, Sichuan University (ZYGD18011).

\section{Footnote}

Reporting Checklist: The authors have completed the CARE reporting checklist. Available at http://dx.doi.org/10.21037/ tau-20-1073

Peer Review File: Available at http://dx.doi.org/10.21037/ tau-20-1073

Conflicts of Interest: All authors have completed the ICMJE uniform disclosure form (available at http://dx.doi. org/10.21037/tau-20-1073). The authors have no conflicts of interest to declare.

Ethical Statement: The authors are accountable for all aspects of the work in ensuring that questions related to the accuracy or integrity of any part of the work are appropriately investigated and resolved. All procedures performed in studies involving human participants were in accordance with the ethical standards of the Ethics committee on biomedical research, West China Hospital of Sichuan University and with the Helsinki Declaration (as revised in 2013). Written informed consent was obtained from the patient.
Open Access Statement: This is an Open Access article distributed in accordance with the Creative Commons Attribution-NonCommercial-NoDerivs 4.0 International License (CC BY-NC-ND 4.0), which permits the noncommercial replication and distribution of the article with the strict proviso that no changes or edits are made and the original work is properly cited (including links to both the formal publication through the relevant DOI and the license). See: https://creativecommons.org/licenses/by-nc-nd/4.0/.

\section{References}

1. Fabiani A, Principi E, Filosa A, et al. An unusual case of primary intrascrotal lipoma. Arch Ital Urol Androl 2016;88:345-6.

2. Srivastava KN, Agarwal A, Siddharth Vikram SS, et al. Huge scrotal lipoma posing a diagnostic dilemma: A case report and review of literature. Urol Case Rep 2017;15:39-41.

3. Riley DS, Barber MS, Kienle GS, et al. CARE guidelines for case reports: explanation and elaboration document. J Clin Epidemiol 2017;89:218-35.

4. Wolfman DJ, Marko J, Gould CF, et al. Mesenchymal Extratesticular Tumors and Tumorlike Conditions: From the Radiologic Pathology Archives. Radiographics 2015;35:1943-54.

5. Fujimura N, Kurokawa K. Primary lipoma of the scrotum. Eur Urol 1979;5:182-3.

6. Livermore GR. Lipoma of the scrotum; case report. J Urol 1948;60:153-5.

7. McCULLOUGH CP. Unusual scrotal lipoma associated with sigmoid diverticulum. Calif Med 1953;79:449-50.

8. Florante J, Leyson J, Doroshow LW, et al. Extratesticular lipoma: report of 2 cases and a new classification. J Urol 1976;116:324-6.

9. Rosenberg R, Williamson MR. Lipomas of the spermatic cord and testis: report of two cases. J Clin Ultrasound 1989;17:670-4.

10. Szmigielski W, Khairat M, Haider A, et al. Huge scrotal lipoma masquerading as haematoma. Clin Radiol 2000;55:479-80.

11. Edelstein RA. Giant spermatic cord lipoma. ScientificWorldJournal 2009;9:1194-6.

12. Kim SO, Im CM, Joo JS, et al. Scrotal primary lipoma with unusual clinical appearance in newborn. Urology 2009;73:1024-5.

13. Sakorafas GH, Polychronopoulos D. Giant scrotal lipoma. Eur J Cancer Care (Engl) 2010;19:e5. 
14. Kaplanoglu V, Kaplanoglu H, Parlak IS, et al. Giant intrascrotal lipoma. BMJ Case Rep 2013;2013:bcr2013200500.

15. Creta M, De Stefano G, Buonopane R, et al. Giant primary scrotal lipoma: A case report. Arch Ital Urol Androl 2017;89:243-4.

16. Yamamichi G, Nakata W, Yamamoto A, et al. Liposarcoma of the spermatic cord associated with scrotum lipoma: A case report and review of the literature. Urol Case Rep 2018;17:114-6.

17. Szewc M, Sitarz R, Moroz N, et al. Madelung's disease - progressive, excessive, and symmetrical deposition of adipose tissue in the subcutaneous layer: case report and literature review. Diabetes Metab Syndr Obes 2018;11:819-25.

18. Nikolić ZS, Jeremić JV, Drčić LJ, et al. Madelung disease: a rare case associated with gynaecomastia and scrotal involvement. J Plast Surg Hand Surg 2013;47:415-8.

Cite this article as: Zheng $\mathrm{W}$, Shi M, Li T, Xu H, Chen Z, Wang X, Bai S, Le W, Yang L, Wei Q. Giant bilateral primary scrotal lipoma along with lipomas in multiple sites of the body: a case report and literature review. Transl Androl Urol 2021;10(2):983-990. doi: 10.21037/tau-20-1073
19. Salmaso GV, Taricco F. Ultrasonographic characteristics of lipoma of the soft tissues. Radiol Med 1994;88:373-7.

20. Hunter JC, Johnston WH, Genant HK. Computed tomography evaluation of fatty tumors of the somatic soft tissues: clinical utility and radiologic-pathologic correlation. Skeletal Radiol 1979;4:79-91.

21. Gupta P, Potti TA, Wuertzer SD, et al. Spectrum of Fatcontaining Soft-Tissue Masses at MR Imaging: The Common, the Uncommon, the Characteristic, and the Sometimes Confusing. Radiographics 2016;36:753-66.

22. Johnson CN, Ha AS, Chen E, et al. Lipomatous Softtissue Tumors. J Am Acad Orthop Surg 2018;26:779-88.

23. Kobayashi A, Sakuma T, Fujimoto M, et al. Diagnostic Utility and Limitations of Immunohistochemistry of p16, CDK4, and MDM2 and Automated Dual-color In Situ Hybridization of MDM2 for the Diagnosis of Challenging Cases of Dedifferentiated Liposarcoma. Appl Immunohistochem Mol Morphol 2019;27:758-63. 